\title{
THE CORONAVIRUS PANDEMIC AND EUROPE'S UNDECLARED ECONOMY: IMPACTS AND A POLICY PROPOSAL
}

Colin C. Williams, Aysegul Kayaoglu

\begin{abstract}
The coronavirus pandemic has led to a loss of revenues for enterprises and workers due to workplace closures and restrictions on movement to 'flatten the curve'. In response, governments have made available temporary financial support to enterprises and workers affected. This paper evaluates a group currently excluded from this support, namely enterprises and workers in the undeclared economy, and a possible government policy response. To identify those involved, a 2019 Eurobarometer survey of undeclared work in Europe is reported. This reveals that one in every 132 European citizens relies wholly on undeclared earnings and the sectors and population groups involved. Given their reduced revenues and inability to access the temporary financial support, a voluntary disclosure initiative is recommended which brings undeclared enterprises and workers into the declared economy and onto the radar of state authorities by offering access to this temporary financial support if they disclose their previous undeclared work.
\end{abstract}

Keywords: coronavirus; COVID-19; informal economy; undeclared work; tax evasion; public policy.

JEL classification: $\mathrm{H} 26, \mathrm{J46}, \mathrm{K} 34, \mathrm{O} 17, \mathrm{P} 2$

\section{INTRODUCTION}

In early 2020, a new strain of coronavirus (SARS-CoV-2) producing a new respiratory disease (COVID-19) began to spread across the world. The World Health Organisation declared a global health emergency on the 30th January and a pandemic on $11^{\text {th }}$ March. By April 2020, and at the time of writing, $81 \%$ of the world's workforce are affected by the full or partial closure of their workplaces to restrict the movement of people in order to reduce the rate at which the virus spreads (International Labour Organisation 2020b). This has had a profound impact on the incomes of businesses and workers. Governments have responded by offering temporary financial support to protect the enterprises and workers affected (for a review, see International Monetary Fund 2020).

This paper evaluates those in the undeclared economy, a group excluded from this financial support to
Colin C. Williams (corresponding author)

Professor

Management School

University of Sheffield

E-mail: C.C.Williams@sheffield.ac.uk

Address: Sheffield University Management School, University of Sheffield,

Conduit Road, Sheffield S10 1FL, United Kingdom

Aysegul Kayaoglu, $\mathrm{PhD}$

Associate Professor

Department of Economics

Istanbul Technical University

E-mail: aysegulkayaoglu@gmail.com 
enterprises and workers (although the workers can sometimes access the social protection available for citizens). Mirroring the consensus of practitioners and academics, the undeclared economy here refers to paid activities not declared to the authorities for the purpose of evading tax and social security contributions and/or labour laws (Aliyev 2015; European Commission 2016; Hodosi 2015; OECD 2017; Williams 2019a; Williams and Windebank 1998; World Bank 2019). The rationales for here discussing the exclusion of enterprises and workers in the undeclared economy from this temporary financial support, is three-fold. Firstly, they are a large proportion of the world's workers and enterprises. Some $61 \%$ of workers globally have their main employment in this sector (International Labour Organisation 2018) and over two-thirds of all businesses start-up their venture unregistered and operating in the undeclared economy (Autio and Fu 2015). Secondly, the current media is awash with articles on how undeclared workers have fallen through the safety net, are without money and there is growing social unrest, manifested for example in raids on grocery stores to acquire food (Follain 2020; He 2020; Johnson and Ghiglione 2020; Lynch 2020; Reuters 2020; Speak 2020). Third and finally, if undeclared workers and enterprises are not supported, those able to do so may out of economic necessity work, even whilst infected, thus exacerbating the spread of the virus (Ebata et al. 2020). In consequence, the aim of this paper is to evaluate the sectors and workers involved, and what governments might do about these enterprises and workers so far excluded from the temporary financial support schemes.

To achieve this, the next section reviews the existing literature on the prevalence and characteristics of the undeclared economy in Europe, which at the time of writing is one of the main epicentres of the coronavirus pandemic. To provide an up-to-date evaluation of the range of sectors and workers affected, section 3 then introduces the data and methods here used, namely a probit regression analysis of a special Eurobarometer survey of undeclared work involving 27,565 interviews conducted in September 2019. Section 4 reveals the industries in which undeclared work is prevalent and the socio-demographic, socioeconomic and spatial characteristics of the undeclared labour force. This is then followed in section 5 by some conclusions and a discussion of the implications for policy and way forward for European national governments.

\section{CORONAVIRUS AND ITS IMPACTS ON THE UNDECLARED ECONOMY}

With the shift towards a more globalised world, the rate at which new viruses can spread has significantly increased. In 1970, for instance, the number of air transport passengers was 310 million but by 2018 numbers were 14 times greater at 4.2 billion (World Bank, 2020). It is therefore unsurprising that following reports in January 2020 of a new strain of coronavirus (SARS-CoV-2) spreading in Wuhan, China resulting in a new disease (COVID-19), this very quickly became a global issue, with the World Health Organisation declaring a global health emergency on the $30^{\text {th }}$ January and a global pandemic on $11^{\text {th }}$ March.

Following this declaration of a pandemic by the World Health Organisation, governments across the world have put in place rules to restrict the movement of their citizens and closed non-essential businesses. Overnight, many enterprises have lost their revenues and workers their incomes. The International Labour Organisation (2020a) have called for a response that protects workers, stimulates the economy and employment, and supports jobs and incomes. The measures recommended include extending social protection to those affected by the pandemic, supporting employment retention (e.g., paid leave), and financial and tax relief for the enterprises affected.

In Europe, which at the time of writing is one of the main epicentres of this pandemic, the European Commission (2020) has sought to achieve this through its Support to mitigate Unemployment Risks in an Emergency (SURE) programme. This provides loans of up to $€ 100$ billion to Member States to fund short-term schemes to protect jobs, employees and the self-employed against the risk of dismissal and loss of income (see International Monetary Fund 2020 and ITUC 2020 for details of national financial support schemes). With this funding, businesses can temporarily reduce the hours of employees or suspend their employment altogether, with government funding provided for the hours not worked, and the self-employed are able to receive temporary income replacement from governments for their lost revenues. This temporary financial support therefore protects jobs and workers deleteriously affected by the coronavirus pandemic, stimulates the economy and supports jobs and incomes. Therefore, these support measures protect businesses from their temporary loss of revenue and workers (both dependent employees and the self-employed) who would have otherwise lost their incomes. In the UK, for example, to keep employees 
on the payroll, businesses can claim $80 \%$ of their employees' wages up to maximum of $£ 2,500$ per employee each month from the UK government, and a taxable grant is available for the self-employed from the UK government worth $80 \%$ of their trading profits up to a maximum of $£ 2,500$ per month along with the deferral of payment of direct and indirect taxes owed (International Monetary Fund 2020).

However, the problem for some enterprises and workers is that they either do not operate in the declared economy or only partially do so. These enterprises and workers will be unable to access these temporary financial support schemes. Such workers and businesses are not some small minority existing in the margins of the economic landscape. Some two billion workers globally, representing $61.2 \%$ of the world employed population, have their main employment in the undeclared economy (International Labour Organisation 2018). Similarly, two-thirds of all businesses globally are not registered at the start-up of operations and this is the case not only in developing countries and transition economies but also in OECD nations (Autio and Fu 2015), and at least half of all businesses worldwide operate on an unregistered basis (Acs et al. 2013). If one adds the unknown proportion of registered enterprises that conduct a portion of their transactions in the undeclared economy, the share of enterprises in the undeclared economy is much higher (OECD 2017; Williams 2017; World Bank 2019). Most workers and enterprises across the globe will be therefore unable to fully or in many cases even partially receive temporary financial support from the current schemes to offset the impacts of the pandemic on their livelihoods.

It might be assumed that only a small minority of businesses and workers operate in the undeclared economy in Europe so this issue of exclusion from temporary financial support is not a major issue. However, Williams and Schneider (2016) estimate that the undeclared economy is the equivalent of $15.8 \%$ of GDP in the EU, whilst Williams et al. (2017a) calculate that in the EU, $11.6 \%$ of all labour input in the private sector is undeclared. A sizeable share of European workers and enterprises will be therefore excluded in full or in part from the temporary financial support being provided by governments to businesses and workers.

This becomes apparent when one examines the various types of enterprise and worker in the undeclared economy. Two types of enterprise operate in the undeclared economy. Firstly, there are unregistered enterprises, which in the main are comprised of sole traders operating on a self-employed basis and micro-enterprises (Williams 2017; Williams et al. 2017b). Often referred to as 'ghosts' since they are hidden from, and their trade unrecorded by, the tax authorities, these unregistered enterprises will be wholly excluded from accessing financial support. Secondly, there are registered businesses that declare only a portion of their work and revenue. These can only access financial support to offset the shortfalls in their declared turnover and for their declared employees.

Turning to undeclared workers, three types exist. Firstly, there are unregistered employees, where the employees are wholly undeclared and have no written contract of employment (Gashi and Williams 2019; Krasniki and Williams 2017). A 2013 EU-wide survey finds that one in 20 (5 per cent) in employment reported not having a written contract of employment. Extrapolating from this, 10.6 million of the 212 million employees in 2013 in the EU-28 were therefore working wholly undeclared with no written contract or terms of employment (Williams and Kayaoglu 2017). These workers will be excluded from the current shortterm financial support for employees. Depending on the system of social insurance in countries, they will perhaps also excluded from welfare benefits, although many governments have bolstered their welfare 'safety net', such as by introducing the temporary enhancement of unemployment insurance benefits and relaxing eligibility rules for benefits (Gaspar and Mauro 2020; International Monetary Fund 2020).

Secondly, there are under-declared employees (Williams 2012; Williams and Bezeredi 2018a). These employees have a declared job but receive two wages: an official declared wage (often paid at the minimum wage rate) and an additional undeclared 'envelope wage.' In 2013, one in 33 declared employees in the EU28 received envelope wages amounting on average to $25 \%$ of their gross salary (Williams and Horodnic 2017b, 2017c). These under-declared employees, depending on the social insurance system, may receive lower welfare benefits than if their full wage had been declared.

Thirdly, there are the bogus self-employed. These workers are registered as self-employed but operate under the same working conditions as direct employees and/or they depend on a single employer for a large share or all their income. In the EU, $4.3 \%$ of all employment is bogus self-employment (Williams and Lapeyre 2017, 2020; Williams and Horodnic 2019a). These misclassified workers will be excluded from the financial support for employees but able to access financial support for the self-employed.

Examining the sectors and activities where undeclared work prevails in the EU, a 2013 Eurobarometer survey finds that those conducting undeclared work most commonly mentioned that they provide home 
repair or renovation services $(19 \%$ of all undeclared workers), $14 \%$ provide gardening services, $13 \%$ household cleaning and ironing, $12 \%$ childcare, $11 \%$ were waiters or waitresses, $7 \%$ provided IT support services, $7 \%$ home removal services, $7 \%$ tutoring and 3\% assistance to an elderly or dependent person. Many of these activities have totally ceased due to the closure of non-essential businesses (e.g., waiting staff). Meanwhile, many of the undeclared workers involved in the provision of undeclared personal services (e.g., elder care, childcare, domestic cleaning, tutoring) will have lost their jobs either due to customers not wanting them in their homes (during the current period of self-isolation) or due to the undeclared workers no longer being able to travel to undertake this work. A concern is that if some of these undeclared workers are continuing to work, due to their lack of alternative financial support, then this may exacerbate the rate of infections, often with dire consequences for their clients who are among the most physically vulnerable in relation to elder care.

This argument that undeclared workers, lacking alternative financial support, might continue to work is further reinforced when one examines who participates in the undeclared economy. In previous studies, a 'marginalisation' thesis has been partially validated which asserts that groups marginalised from the declared economy are more likely to be in the undeclared workforce. Undeclared work is found to be more prevalent in countries with a lower GDP per capita (Schneider and Williams 2013; Williams 2015), less affluent regions (Kesteloot and Meert 1999; Williams and Windebank 2001) and rural areas (Williams 2004). Similarly, the unemployed disproportionately engage in undeclared work (Ahmad and Nobil 2008; Castree et al. 2004; Surdej and Ślęzak 2009), those with less time in full-time education (Slavnic 2010), and poorer groups (Katungi et al. 2006; Williams 2004). In an indepth analysis of the 2013 Eurobarometer survey of undeclared work, Williams and Horodnic (2017a) find that that the unemployed and those with difficulties paying the household bills are more likely to engage in undeclared work, but not those with less full-time education, living in rural areas and European regions with lower GDP per capita. There is also recent evidence that international migration is associated with increasing participation in undeclared work. This is not solely due to migrant groups being more likely to engage in undeclared work in their host country, but also because those who have been abroad and then return to their home country are significantly more likely to engage in undeclared work than non-migrant groups (Williams and Efendic, forthcoming). The implication is that the recent return of these migrants to their home country, having lost their jobs abroad due to the pandemic, might lead to an upsurge in undeclared work.

Examining the reasons for engaging in undeclared work, the view in the marginalisation thesis is that populations marginalised from the declared economy do so out of economic necessity as a survival tactic due to the absence of alternative means of livelihood (Slavnic 2010). Put another way, engagement in undeclared work is portrayed to result from participants 'exclusion' from the declared economy (Davis 2006; Gallin 2001; ILO 2018). Nevertheless, other literature portrays undeclared work to result from a decision to voluntarily 'exit' the declared economy, such as because of high taxes and over-burdensome regulations (De Soto 1989, 2001; Maloney 2004) or discontent with government (Horodnic 2018; Williams 2017). Yet other literature portrays a dual undeclared labour market composed of an exclusion-driven 'lower tier' and an exit-driven 'upper tier' of undeclared workers (Fields 1990, 2005; Williams and Bezeredi 2018b; Williams et al. 2017c).

Reporting an EU-wide 2013 survey, Williams et al. (2017c) identify that $24 \%$ of undeclared workers are purely exclusion driven, $45 \%$ purely exit driven and $31 \%$ display mixed reasons. Thus, the number in the exclusion-driven lower tier are half those in the exitdriven upper tier. This, however, varies across EU regions. In Southern Europe, there is a 2:1 ratio between purely exclusion-driven and purely exit-driven undeclared workers, whilst in Nordic nations and Western Europe, it is the inverse, with a 6.8:1 ratio and 3.6:1 ratio between exit-driven and exclusion-driven undeclared workers. Across the EU, the exclusion-driven 'lower tier' is significantly more populated by unemployed persons and those living in Central and East European countries whilst the exit-driven 'upper tier' by people with few financial difficulties and those living in Nordic countries. From this perspective, it is therefore those in the lower tier who perhaps have having difficulties during the current coronavirus pandemic if they are excluded from accessing the financial support offered to enterprises and workers.

Having reviewed the existing evidence on the prevalence and characteristics of the undeclared economy in Europe, it is apparent that no up-to-date EU-wide analysis exists of enterprises and workers participating in undeclared work who will have been affected by the coronavirus pandemic. Here, therefore, a Eurobarometer survey on undeclared work conducted in September 2019, just before the onset of the pandemic, and made public in March 2020, is reported. 


\section{METHODOLOGY}

To evaluate who participates in undeclared work and will have been affected by the workplace closures and restrictions on movement resulting from the coronavirus pandemic, data is reported from Eurobarometer special survey 92.1 on undeclared work, which involved 27,565 interviews being conducted in September 2019 in 28 European countries (the $27 \mathrm{EU}$ member states and the UK). All interviews were in the national language with adults aged 15 years and older. A multi-stage random (probability) sampling methodology was used, which ensured that on the issues of gender, age, region and locality size, both the national and each level of the sample is representative in proportion to its population size.
To analyse participation in undeclared work, the dependent variable with value 1 for respondents answering 'yes' to the question of 'Apart from a regular employment, have you yourself carried out any undeclared paid activities in the last 12 months?', and value 0 otherwise. Similar to previous analyses of the 2007 and 2013 Eurobarometer surveys of undeclared work (Williams and Horodnic 2016, 2017a), the control variables selected include a range of socio-demographic, socio-economic and spatial variables (see Table 1).

Probit regression analysis is used in the empirical analysis because our dependent variable is a binary variable. The maximum likelihood method is used to estimate the objective function. The log-likelihood function for the probit model is:

Table 1. Control variables used: definitions

$\begin{array}{ll}\text { Variables } & \text { Definition } \\ \text { Gender } & \text { A dummy variable with value } 0 \text { for females and } 1 \text { for males } \\ \text { Age } & \text { A categorical variable indicating the age interval of a respondent with value one for those aged } 15-24, \\ & \text { value } 2 \text { for aged } 25 \text { to } 39, \text { value } 3 \text { for aged } 40 \text { to } 54 \text {, and value } 5 \text { for those who are aged } 55 \text { or above. }\end{array}$

Marital status A categorical variable for the marital status of respondents with value 1 for (re)married, value 2 for single living with a partner, value 3 for single, value 4 for divorced or separated, value 5 for widow, and value 6 for others.

Household type A categorical variable for the household situation with value 1 for single household without children, value 2 for single household with children, value 3 for multiple household without children, and value 4 for household with children.

Number of This is a truncated variable for the number of children in households who are younger than 10 years children under old. If there is no children aged below 10 in a household than it is equal to 0 which is the first category 10 years old whereas it is always equal to value 5 if there are more than and equal to 4 children below age 10 in a household.

Stopped full- $\quad$ A categorical variable for the education level of respondents. It is equal to 1 if s/he stopped full-time time education education below age 15, value 2 if stopped between 16-19, value 3 if stopped at an age older than 19, value 4 if $s / h e$ still studies, and value 5 if $s /$ he does not have any full-time education.

Labour market A categorical variable grouping respondent by their socio-professional category with value 1 for selfstatus employed, value 2 for managers, value 3 for other white collars, value 4 for manual workers, value 5 for house person, value 6 for unemployed, value 7 for retired, and value 8 for students.

Difficulties pay- A categorical variable for the respondents' difficulties in paying bills with value 1 for almost never/never, ing bills value 2 for occasionally, and value 3 for having difficulties most of the time.

Urban/rural A categorical variable for the area where the respondent lives with value 1 for rural area or village, value 2 for small or middle-sized town, and value 3 for large town.

Southern A dummy variable equals to 1 if the respondent is from Greece, Spain, Portugal, Cyprus, Italy or Malta Europe

Western Europe A dummy variable equals to 1 if the respondent is from Belgium, Luxembourg, the Netherlands, Austria, Ireland, the United Kingdom, France or Germany

East-Central A dummy variable equals to 1 if the respondent is from Latvia, Croatia, Romania, Slovakia, Bulgaria, Europe Hungary, Lithuania, Czech Republic, Estonia, Poland or Slovenia.

Nordic nations A dummy variable equals to 1 if the respondent is from Denmark, Finland or Sweden. 
$\ln L_{i}(\boldsymbol{\beta})=\mathrm{y}_{\mathrm{i}} \log \left\{\phi\left(\mathrm{x}_{\mathrm{i}} \beta\right)\right\}+\left(1-\mathrm{y}_{\mathrm{i}}\right) \log \left\{1-\phi\left(\mathrm{x}_{\mathrm{i}} \beta\right)\right\}$

where $\phi$ is the standard cumulative normal distribution function which is numerically maximized with respect to $\beta$. Using probit analysis, the following model is adopted:

$$
\operatorname{Pr}\left(y_{i}^{*}>0 \mid \boldsymbol{x}_{i}\right)=\phi\left(\boldsymbol{x}_{i} \boldsymbol{\beta}\right)
$$

The dependent variable of the model $\left(y_{i}^{*}\right)$ is a latent variable, which represents engagement in undeclared work and is linearly related to a set of factors $\mathbf{x}$ and a disturbance process $\boldsymbol{\varepsilon}$. Control variables are described in Table 1.

\section{RESULTS}

As Table 2 reveals, 3.6\% of the European citizens surveyed (one in 28) had engaged in undeclared work in the year prior to the survey undertaken in September 2019. Of those participating in undeclared work, their work was concentrated in particular sectors: $27 \%$ engaged in undeclared work in the personal services sector (e.g., childcare, care for the elderly, cleaning services); $19 \%$ conducted their undeclared work in the construction sector; $17 \%$ in the hospitality sector; $10 \%$ in the retail or repair services sector; $8 \%$ in education, health and social work services; $6 \%$ in agriculture; $5 \%$ in transport, and $4 \%$ in industry and manufacturing.

When questioned about the more precise activities they conduct: $21 \%$ of those engaging in undeclared work undertake home repair or renovation services; $14 \%$ babysitting; $14 \%$ undeclared work as a waitress or waiter; $12 \%$ domestic cleaning or ironing; $12 \%$ gardening services; $10 \%$ provide assistance to a dependent or elderly person; $10 \%$ tutoring services; $6 \%$ household removal services; $5 \%$ professional services (e.g., accounting, consulting, project management); $5 \%$ writing or translation services; $5 \%$ creative, multimedia and software services (e.g., design, marketing support, wen or software development); 4\% IT assistance or administrative and clerical tasks, and 3\% passenger transport services.

Many of these sectors and activities have been severely affected by the current pandemic. The $14 \%$ of the undeclared workforce employed as waiters and waitresses are now without this source of income because of the closure of bars, restaurants and cafes, as are the $6 \%$ providing house removal services because of the temporary cessation of people moving house, and the $3 \%$ providing passenger services have witnessed a severe downturn in trade because of restrictions on movement. Many providing personal services in others' households (e.g., domestic cleaning and ironing, babysitting, assistance to dependent or elderly people) will also have witnessed major reductions in earnings as households self-isolate (and cancel such services fearing infection) and even if demand persists, travel restrictions will have made it difficult to provide such undeclared services.

Analysing the employment relationships of these one in 28 European citizens who undertaken undeclared work, $50 \%$ work on an own-account selfemployed basis, $16 \%$ engage in undeclared waged employment for an employer, $11 \%$ both undeclared own-account work and waged employment, $8 \%$ work for a partner or family businesses (e.g., in family-owned businesses), whilst $15 \%$ either refused to answer or did not know. Furthermore, analysing how their undeclared activities fit into their wider portfolio of work, $21 \%$ of those engaging in undeclared work ( $0.8 \%$ of all European citizens surveyed, or one in every 132) depend purely on undeclared work for all their income. In consequence, a significant minority of European citizens are currently wholly excluded from the temporary financial support offered to declared employees and the self-employed in response to the coronavirus pandemic. These undeclared workers relying wholly on undeclared earnings are concentrated in Southern Europe, where they constitute $27 \%$ of all undeclared workers.

Who, therefore, engages in undeclared work in Europe? The descriptive statistics in Table 2 reveals men are more likely than women, as are younger age groups more likely than older age groups. Single people and single people living with a partner are also over-represented among undeclared workers, as are single person households. Although the years spent in full-time education makes little difference to participation, students are over-represented, as are the selfemployed, manual workers and unemployed. Those having difficulty paying the bills most of the time are also over-represented, and although few variations exist between urban and rural areas, those in Western Europe and the Nordic nations are more likely to engage in undeclared work than those in East-Central Europe and Southern Europe.

To examine whether these descriptive findings remain valid when other variables are introduced and held constant, Table 3 reports the marginal effects of the probit regression analysis. Model 1 considers only the socio-demographic characteristics of participants, model 2 adds their socio-economic characteristics and model 3 (the full specification model) adds their spatial characteristics. Reporting the results of the full specification model, the finding after controlling for 
Table 2. Descriptive statistics of participation in undeclared work in Europe, 2019

\begin{tabular}{|c|c|c|}
\hline Variable & $\%$ of all surveyed & $\%$ of all undeclared workers \\
\hline Number & 26,565 & 961 \\
\hline All (\%) & 100.0 & 3.6 \\
\hline \multicolumn{3}{|l|}{$\begin{array}{l}\text { Socio-demographic variables } \\
\text { Gender }\end{array}$} \\
\hline Male & 45.3 & 59.3 \\
\hline Female & 54.7 & 40.7 \\
\hline \multicolumn{3}{|l|}{ Age } \\
\hline $15-24$ & 8.7 & 17.6 \\
\hline $25-39$ & 20.1 & 30.0 \\
\hline $40-54$ & 23.8 & 27.4 \\
\hline $55+$ & 47.4 & 25.0 \\
\hline \multicolumn{3}{|l|}{ Marital status } \\
\hline (Re)Married & 52.4 & 36.7 \\
\hline Single living with partner & 12.1 & 20.8 \\
\hline Single & 16.9 & 27.9 \\
\hline Divorced or separated & 8.0 & 10.0 \\
\hline Widow & 10.1 & 3.6 \\
\hline Other & 0.5 & 1.0 \\
\hline \multicolumn{3}{|l|}{ Household type } \\
\hline Single household without children & 29.9 & 34.6 \\
\hline Single household with children & 5.3 & 7.4 \\
\hline Multiple household without children & 35.6 & 29.2 \\
\hline Household with children & 29.5 & 28.8 \\
\hline \multicolumn{3}{|l|}{ Number of children below age 10} \\
\hline 0 & 83.0 & 80.3 \\
\hline 1 & 10.2 & 12.4 \\
\hline 2 & 5.6 & 5.6 \\
\hline 3 & 0.9 & 0.8 \\
\hline $4+$ & 0.3 & 0.8 \\
\hline \multicolumn{3}{|l|}{ Socio-economic variables } \\
\hline \multicolumn{3}{|l|}{ Stopped full-time education } \\
\hline $15-$ & 13.5 & 8.5 \\
\hline $16-19$ & 43.9 & 42.7 \\
\hline $20+$ & 35.5 & 35.0 \\
\hline Still studying & 6.2 & 12.6 \\
\hline No full-time education & 0.9 & 1.2 \\
\hline \multicolumn{3}{|l|}{ Labour market status } \\
\hline Self-employed & 6.9 & 11.9 \\
\hline Managers & 10.6 & 8.0 \\
\hline Other white collars & 12.8 & 11.5 \\
\hline Manual workers & 20.1 & 26.5 \\
\hline House person & 5.3 & 3.8 \\
\hline Unemployed & 4.9 & 13.3 \\
\hline Retired & 33.1 & 12.8 \\
\hline Students & 6.1 & 12.3 \\
\hline \multicolumn{3}{|l|}{ Difficulties paying bills } \\
\hline Almost never/never & 68.4 & 53.4 \\
\hline From time to time & 24.0 & 28.5 \\
\hline Most of time & 7.7 & 18.1 \\
\hline \multicolumn{3}{|l|}{ Spatial characteristics } \\
\hline \multicolumn{3}{|l|}{ Urban/rural } \\
\hline Rural area or village & 34.3 & 33.9 \\
\hline Small or medium sized town & 37.2 & 39.6 \\
\hline Large town & 28.5 & 26.5 \\
\hline \multicolumn{3}{|l|}{ EU region } \\
\hline Southern & 18.4 & 14.9 \\
\hline Western & 30.1 & 33.2 \\
\hline East-Central & 40.3 & 38.7 \\
\hline Nordic nations & 11.2 & 13.2 \\
\hline
\end{tabular}

Source: authors' calculations based on the 2019 Eurobarometer 92.1 survey 
Table 3. Marginal effects of the probit regression models of the likelihood of participating in undeclared work in Europe, 2019

\begin{tabular}{|c|c|c|c|c|c|c|c|c|c|}
\hline & \multicolumn{3}{|c|}{ Model 1} & \multicolumn{3}{|c|}{ Model 2} & \multicolumn{3}{|c|}{ Model 3} \\
\hline & $\mathrm{dy} / \mathrm{dx}$ & $\mathrm{p}$-value & se & $\mathrm{dy} / \mathrm{dx}$ & $p$-value & se & $\mathrm{dy} / \mathrm{dx}$ & $\mathrm{p}$-value & se \\
\hline \multicolumn{10}{|l|}{ Socio-demographic variables } \\
\hline Men & .019 & $* * *$ & .002 & .019 & $* * *$ & .002 & .018 & $* * *$ & .002 \\
\hline \multicolumn{10}{|l|}{ Age (Ref. category: 15-24) } \\
\hline $25-39$ & -.005 & & .004 & -.002 & & .005 & -.002 & & .004 \\
\hline $40-54$ & -.013 & $* * *$ & .004 & -.009 & * & .005 & -.011 & ** & .005 \\
\hline $55+$ & -.035 & $* * *$ & .004 & -.019 & $* * *$ & .006 & -.021 & $* * *$ & .006 \\
\hline \multicolumn{10}{|l|}{ Marital status (RC: (Re)Married) } \\
\hline Single living with partner & .021 & $* * *$ & .003 & .018 & $* * *$ & .003 & .017 & $* * *$ & .003 \\
\hline Single & .022 & $* * *$ & .007 & .013 & * & .007 & .012 & * & .007 \\
\hline Divorced or separated & .026 & $* * *$ & .007 & .017 & $* *$ & .007 & .015 & ** & .007 \\
\hline Widow & - & - & - & - & - & - & & & \\
\hline \multicolumn{10}{|c|}{ Household Type (RC: Single Household without children) } \\
\hline Single Household with children & .013 & $* *$ & .005 & .011 & $* *$ & .005 & .010 & * & .005 \\
\hline Multiple Household without children & .005 & & .006 & .002 & & .007 & .002 & & .007 \\
\hline Household with children & .009 & & .007 & .003 & & .007 & .003 & & .007 \\
\hline \multicolumn{10}{|l|}{ Number of Children below age 10 (RC: 0 ) } \\
\hline 1 & -.004 & & .004 & -.005 & & .004 & -.006 & & .004 \\
\hline 2 & -.010 & * & .006 & -.009 & * & .005 & -.012 & ** & .006 \\
\hline 3 & -.015 & & .013 & -.019 & & .013 & -.022 & * & .013 \\
\hline $4+$ & .036 & $* * *$ & .013 & .031 & ** & .012 & .029 & $* *$ & .012 \\
\hline \multicolumn{10}{|l|}{$\begin{array}{l}\text { Socio-Economic Variables } \\
\text { Stopped Full-time Education (RC: 15- ) }\end{array}$} \\
\hline 16-19 & & & & .005 & & .004 & .003 & & .004 \\
\hline $20+$ & & & & .010 & ** & .004 & .006 & & .005 \\
\hline Still studying & & & & .001 & & .007 & -.005 & & .007 \\
\hline No full-time education & & & & .029 & ** & .011 & .021 & * & .012 \\
\hline \multicolumn{10}{|l|}{ Labour Market Status (RC: Self-employed) } \\
\hline Managers & & & & -.027 & $* * *$ & .005 & -.029 & $* * *$ & .005 \\
\hline Other white collars & & & & -.022 & $* * *$ & .005 & -.023 & $* * *$ & .005 \\
\hline Manual workers & & & & -.012 & $* * *$ & .004 & -.014 & $* * *$ & .004 \\
\hline House person & & & & -.019 & $* * *$ & .007 & -.020 & $* * *$ & .007 \\
\hline Unemployed & & & & .008 & * & .005 & .005 & & .005 \\
\hline Retired & & & & -.035 & $* * *$ & .005 & -.039 & $* * *$ & .005 \\
\hline Students & & & & - & - & - & - & - & - \\
\hline \multicolumn{10}{|l|}{ Difficulties paying bills (RC: Almost never/never) } \\
\hline From time to time & & & & .009 & $* * *$ & .002 & .013 & $* * *$ & .003 \\
\hline Most of time & & & & .035 & $* * *$ & .003 & .040 & $* * *$ & .003 \\
\hline \multicolumn{10}{|l|}{ Spatial characteristics } \\
\hline $\begin{array}{l}\text { Urban/rural (RC: Rural area or village) } \\
\text { Small or medium sized town }\end{array}$ & & & & & & & -.001 & & .003 \\
\hline Large town & & & & & & & -.007 & $* *$ & .003 \\
\hline \multicolumn{10}{|l|}{ EU region (RC: East-Central) } \\
\hline Southern & & & & & & & -.419 & ** & .184 \\
\hline Western & & & & & & & .141 & & .207 \\
\hline Nordic nations & & & & & & & .412 & & .283 \\
\hline 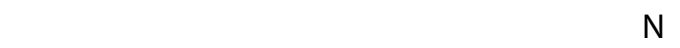 & & & 26,253 & & & 6,253 & & & 26,253 \\
\hline Pseudo $\mathrm{R}^{2}$ & & & 0.0497 & & & .0807 & & & 0.0868 \\
\hline$\chi^{2}$ & & & 379.15 & & & 66.86 & & & 731.86 \\
\hline$p>$ & & & 0.0000 & & & .0000 & & & 0.0000 \\
\hline
\end{tabular}

Notes:

Statistically significant at ${ }^{* * *} p<0.01,{ }^{* *} p<0.05,{ }^{*} p<0.1$ (robust standard errors in parentheses). All coefficients are compared to the reference category, shown in brackets. We kept in the analysis the individuals for which data on each and every independent variable is available. When the models are regressed with clustering the individuals by country, the direction of the associations and the significances do not change for the independent variables discussed in the paper. (with $p<0.05$ or $p<0.01$ ).

Source: authors' calculations based on the 2019 Eurobarometer 92.1 survey 
other variables is that men have a $1.8 \%$ significantly higher probability of participating in undeclared work than women, whilst older age groups have a significantly lower probability of engaging in undeclared work than younger age groups. Single person households, single people living with a partner and the divorced or separated all have a significantly higher likelihood of engaging in undeclared work than (re) married people, whilst those with two or three children have a significantly lower probability than those without children, although those with four or more children have a greater likelihood of engaging in undeclared work than those without children. The age at which full-time education stopped makes no significant difference to the likelihood of participation, except for those who have had no full-time education who are more likely to engage than those who finished full-time education at 15 years old or younger. Self-employed individuals are significantly more likely to engage in undeclared work than all employee groups and the retired. Those having difficulty paying their household bills most of the time have a $4 \%$ higher probability of engaging in undeclared work than those who never or almost never have difficulties, and those who from time to time have difficulties have a $1.3 \%$ higher probability. Citizens living in large urban areas are significantly less likely to engage in undeclared work than those living in a rural area or village. Those living in Southern Europe have a $41.9 \%$ lower probability of participating in undeclared work than those in East-Central European countries.

\section{DISCUSSION AND CONCLUSIONS}

The problem that has been addressed in this paper is that the short-term financial support being provided to workers and businesses in response to the coronavirus pandemic only substitutes for the loss of declared revenues of enterprises, employees and the self-employed. There is no support available for enterprises, employees and the self-employed operating in the undeclared economy who have lost revenue, except for any welfare benefits available. This has been here shown to affect 3.6\% (one in 28) of all European citizens who report in the 2019 Eurobarometer survey that they participated in undeclared work, and especially the $21 \%$ of those engaged in undeclared work who depend solely on undeclared work for all their income $(0.8 \%$, or one in every 132 , of all European citizens). These undeclared workers are now largely unable to earn a livelihood. Analysing the industries and workers involved, undeclared work has been shown to be particularly prevalent in the personal service (e.g., childcare, eldercare, cleaning services), construction, hospitality and retail sectors, and the undeclared workforce disproportionately composed of men, younger age groups, single person households, single people living with a partner and the divorced or separated, the self-employed, those having difficulties paying their household bills most of the time, those living in a rural area or village, and in East-Central European countries.

What is to be done about those enterprises and workers who were working in the undeclared economy prior to the pandemic? Before the current crisis, the goal of European governments was to transform undeclared work into declared work (European Commission, 2016). To achieve this, the policy approach was based on the view that enterprises and workers engaged in undeclared work when the expected costs (i.e., the likelihood of being caught and punished) were lower than the benefits of doing so (Allingham and Sandmo 1972; Grabiner 2000; Hasseldine and Li 1999; OECD 2017; Richardson and Sawyer 2001; Williams and Franic 2016; World Bank 2019). To change this cost/benefit ratio to make declared work a rational choice, European governments focused upon raising the costs of participating in undeclared work. This was achieved by increasing the sanctions and probability of detection and doing this was widely accepted by European governments as the most important and effective way of transforming undeclared work into undeclared work (see Williams 2019). The result was that scholars and governments paid little attention to increasing the benefits of declared work to change the cost/benefit ratio. Nevertheless, with the pandemic, increasing the penalties and risk of detection has become obsolete since most undeclared work has now ceased. However, increasing the benefits of declared work to pull enterprises and workers into the declared economy remains an option. The current temporary financial support available to those in declared work provides an opportunity to attract these undeclared enterprises and workers out of the shadows and to bring them onto the radar of the state authorities to facilitate compliant behaviour in future by these workers and enterprises.

This could be achieved using a voluntary disclosure initiative. These schemes enable those voluntarily disclosing to the authorities their past undeclared work to have the penalties waived that would have applied, if they are compliant in the future (see Williams 2014, 2017). Voluntary disclosure schemes thus traditionally encourage enterprises and workers to come out of the shadows by threatening them with high fines after the voluntary disclosure period. In the present-day, 
these schemes could instead offer an incentive. Their current loss of revenue provides a push for these enterprises and workers to seize the opportunity to voluntarily disclose. If given access to the temporary financial support being offered to declared enterprises and workers, in return for voluntarily disclosing their previous undeclared work, this would provide a powerful incentive for them to make use of any voluntary disclosure scheme introduced in the current pandemic period.

Voluntary disclosure schemes are a tried and tested method for tackling undeclared work. In the UK, a VAT short-term incentive scheme in 2003 offered businesses the opportunity to regularise their VAT situation without penalty. It cost the tax authorities $£ 500,000$ in marketing costs and $£ 2.7$ million in penalties foregone. They received 3,000 registrations raising $£ 11.4$ million in tax and an additional $£ 2.5$ million in fines applied to those not continuing to comply, with a resultant return-to-cost ratio of 23:1 (National Audit Office 2008). In 2001 in Italy, a voluntary disclosure scheme to encourage undeclared enterprises and workers to formalise either by fully formalising straight away or doing so gradually over a three-year period, produced 1,794 declarations from enterprises and 3,854 new declared workers, although there was also a larger 'silent' formalisation in that 385,000 extra declared workers were registered that year during a time of economic stagnation (Meldolesi 2003).

In consequence, introducing a voluntary disclosure scheme to encourage undeclared enterprises and workers to declare their past undeclared work (which can be either with or without penalty) and in return, providing them with access to the temporary financial support being provided to declared enterprises and workers, could be an effective approach for transforming undeclared workers and enterprises into compliant workers and businesses. On the one hand, this would provide enterprises and workers in the undeclared economy with the temporary financial support needed. On the other hand, and more importantly, this scheme would attract them out of the shadows and into the declared economy. This initiative, of course, may well not be feasible in the developing world where different approaches will be needed to provide support to those in the undeclared economy.

This paper has confined itself to the impacts of COVID-19 on those working in the undeclared economy prior to the pandemic and how to bring them into the declared economy in the aftermath. However, there is also a question of whether there will be a growth of undeclared work after the lockdown period. Firstly, the prevalence of undeclared work after the lockdown in the recovery period will depend on the effectiveness of the national rescue packages, as well as how their effectiveness varies across different industries. If ineffective, then the undeclared economy may fill the gaps left by the demise of declared enterprises. Secondly, the prevalence of undeclared work in the recovery period will depend on whether governments withdraw the financial support offered in the lockdown phase in a way that enables businesses and jobs to survive. Thirdly, it depends on synchronising the timing between sectors recommencing trade and the demand of citizens and other businesses for their products and services. Smoothing the transition from the lockdown phase, through the recovery phase, to the fully operational phase is therefore perhaps the key to preventing greater dependency on the undeclared economy. This will require an unparalleled level of, and capacity for, economic management by national governments. Fourth and finally, its prevalence afterwards will in part depend on the success of the above voluntary disclosure scheme in bringing undeclared workers and enterprises out of the shadows and transforming them into compliant workers and businesses who are on the radar of the state authorities.

In conclusion, if this paper stimulates European governments to recognise the problems being witnessed by enterprises and workers in the undeclared economy and helps identify their prevalence (with the caveat that direct surveys such as this Eurobarometer survey under-estimate the level of participation in undeclared work) and sectors and population groups involved, then one of its intentions will have been achieved. If the paper also leads governments to recognise that action is needed, and encourages the feasibility of a voluntary disclosure initiative to be considered which uses the temporary financial support being provided to declared enterprises and workers as an incentive to bring undeclared enterprises and workers out of the shadows, then it will have achieved its fuller intention.

\section{REFERENCES}

Acs, Z., Desai, S., Stenholm, P., and Wuebeker, R. 2013. Institutions and the rate of formal and informal entrepreneurship across countries. Frontiers of Entrepreneurship Research 35 (15): 1-24.

Ahmad, A., and Nobil, M. 2008. Dead men working: time and space in London's ('illegal') migrant economy. Work, Employment and Society 22 (2): 301-318.

Aliyev, H. 2015. Post-Soviet informality: towards theorybuilding. International Journal of Sociology and Social Policy 35 (3-4): 182-198. 
Allingham, M., and Sandmo, A. 1972. Income tax evasion: a theoretical analysis. Journal of Public Economics 1 (2): 323-338.

Autio, E., and Fu, K. 2015. Economic and political institutions and entry into formal and informal entrepreneurship. Asia Pacific Journal of Management 32 (1): 67-94.

Barbour, A., and Llanes, M. 2013. Supporting people to legitimise their informal businesses. York: Joseph Rowntree Foundation.

Button, K. 1984. Regional variations in the irregular economy: a study of possible trends. Regional Studies 18(3): 385-392.

Castree, N., Coe, N., Ward, K., and Samers, M. 2004. Spaces of work: global capitalism and the geographies of labour. London: Sage.

Davis, M. 2006. Planet of Slums. London: Verso.

De Soto, H. 1989. The Other Path: the economic answer to terrorism. London: Harper and Row.

De Soto, H. 2001. The Mystery of Capital: why capitalism triumphs in the West and fails everywhere else. London: Black Swan.

Ebata, A., Mader, P., and Bloom, G. 2020. Precarious and informal work exacerbates spread of coronavirus. Brighton: Institute of Development Studies

European Commission 2016. Decision (EU) 2016/344 of the European Parliament and of the Council of 9 March 2016 on establishing a European Platform to enhance cooperation in tackling undeclared work. http://data.europa. eu/eli/dec/2016/344/oj (accessed 30 March 2020).

European Commission 2020. COVID 19- Economic package - multiannual financial framework 2014-2020. Brussels: European Commission.

Fields, G.S. 1990. Labour market modelling and the urban informal sector: theory and evidence. In The Informal Sector Revisited, edited by D. Turnham, B. Salome, and A. Schwarz, 49-69. Paris: OECD.

Fields, G.S. 2005. A Guide to Multisector Labor Market Models. Washington DC: World Bank.

Follain, J. 2020. Italy Readies Emergency Cash for Workers in Underground Economy. Bloomberg. https://www.bloomberg.com/news/articles/2020-03-31/italy-readies-emergency-cash-for-workers-in-underground-economy

Gallin, D. 2001. Propositions on trade unions and informal employment in time of globalization. Antipode 19(4): 531-549.

Gashi, A. and Williams, C.C. 2019. Evaluating the prevalence and distribution of unregistered employment in Kosovo: lessons from a 2017 survey. The South East European Journal of Economics and Business 14(1): 7-20

Gaspar, V. and Mauro, P. 2020. Fiscal policies to protect people during the coronavirus outbreak. https://blogs.imf. org/2020/03/05/fiscal-policies-to-protect-people-during-the-coronavirus-outbreak/
Grabiner, L. 2000. The Informal Economy. London: HM Treasury.

Hasseldine, J., and Li, Z. 1999. More tax evasion research required in new millennium. Crime, Law and Social Change 31(1): 91-104.

He, G. 2020. Why NYC's Undocumented Restaurant Workers Are the Forgotten Victims of the Shutdown. Eater New York. https://ny.eater.com/2020/3/31/21199490/ nyc-restaurant-undocumented-worker-coronavirus

Hodosi, A. 2015. Perceptions of irregular immigrants' participation in undeclared work in the United Kingdom from a social trust perspective. International Journal of Sociology and Social Policy 35(5/6): 375-389.

Horodnic, I.A. 2018. Tax morale and institutional theory: a systematic review. International Journal of Sociology and Social Policy 38(9/10): 868-886.

International Monetary Fund. 2020. Policy responses for COVID-19. https://www.imf.org/en/Topics/ imf-and-covid19/Policy-Responses-to-COVID-19

International Labour Organisation. 2018. Women and Men in the Informal Economy: Statistical Picture. Geneva: International Labour Organisation.

International Labour Organisation. COVID-19 and the world of work: impact and policy responses. Geneva: ILO.

International Labour Organisation. 2020b. COVID-19 and the world of work: updated estimates and analysis. Geneva: ILO.

International Trade Union Confederation 2020. Putting people first: 12 governments show the world how to protect lives, jobs and incomes. Brussels: International Trade Union Confederation.

Johnson, M., and Ghiglione, D. 2020. 'Pasta and beans' - Italy's shadow workers are out of the safety net. Financial Times. https://www.ft.com/ content/08847c08-9582-4c48-9d2d-319f8593da19

Karabchuk, T., and Zabirova, A. 2018. Informal employment in service industries: estimations from nationally representative Labour Force Survey data of Russian Federation. The Service Industries Journal 38(11-12): 742-771.

Katungi, D., Neale, E., and Barbour, A. 2006. People in lowpaid informal work. York: Joseph Rowntree Foundation.

Kesteloot, C., and Meert, H. 1999. Informal spaces: the geography of informal economic activities in Brussels. International Journal of Urban and Regional Research 23(2): 232-251.

Krasniki, B.A., and Williams, C.C. 2017. Explaining individual- and country-level variations in unregistered employment using a multi-level model: evidence from 35 Eurasian countries. South-East European Journal of Economics and Business 12(2): 61-71.

Lynch, R. 2020. Army of 'hidden' workers in the grey economy risk spreading virus. Daily Telegraph. https://www.telegraph.co.uk/business/2020/03/25/ 
uks-army-hidden-workers-grey-economy-risk-spreading-virus/

Maloney, W.F.2004.Informality revisited.World Development 32(7): 1159-1178.

Meldolesi, L. 2003. Policy for the regulation of the underground economy and employment. Review of Economic Conditions in Italy 1(1): 89-116.

National Audit Office 2008. Tackling the Hidden Economy. London: National Audit Office.

OECD 2017. Shining light on the shadow economy: opportunities and threats. Paris: OECD.

Reuters 2020. Amid Europe's Lockdowns, No Safety Net for Millions in Black Economy. The New York Times. https:// uk.reuters.com/article/us-health-coronavirus-blackeconomy/amid-europes-lockdowns-no-safety-net-formillions-in-black-economy-idUKKBN21J4LS

Richardson, M., and Sawyer, A. 2001. A taxonomy of the tax compliance literature: further findings, problems and prospects. Australian Tax Forum 16(2): 137-320.

Schneider, F., and Williams, C.C. 2013. The shadow economy. London: Institute of Economic Affairs.

Slavnic, Z. 2010. Political economy of informalisation. European Societies 12(1): 3-23.

Speak, C. 2020. Coronavirus: Fears in Italy shift to growing number who can't afford to eat after shutdown. The Local Italy. https://www.thelocal.it/20200401/as-virusreaches-plateau-in-italy-concern-shifts-to-growingnumbers-who-cant-afford-to-eat

Surdej, A., and Ślęzak, E. 2009. Formal and informal work in a transition economy: the case of Poland. In Formal and Informal Work: the hidden work regime in Europe, edited by B. Pfau-Effinger, L. Flaquer, and P.H. Jensen, 89-116. London: Routledge.

Williams, C.C. 2004. Cash-in-Hand Work: the underground sector and the hidden economy of favours. Basingstoke: Palgrave Macmillan.

Williams, C.C. 2012. Cross-national variations in the underreporting of wages in South-East Europe: a result of over-regulation or under-regulation? The South East European Journal of Economics and Business 7(1): 53-61.

Williams, C.C. 2014. Confronting the Shadow Economy: evaluating tax compliance and behaviour policies. Cheltenham: Edward Elgar.

Williams, C.C. 2015. Explaining cross-national variations in the scale of informal employment: an exploratory analysis of 41 less developed economies. International Journal of Manpower 36(2): 118-135.

Williams, C.C. 2017. Entrepreneurship in the Informal Sector: An Institutional Perspective. London: Routledge.

Williams, C.C. 2019a. The Informal Economy. New York: Columbia University Press.

Williams, C.C. 2019b. Tackling undeclared work in the European Union: an evaluation of government policy approaches. UTMS Journal of Economics 10(2): 135-147.
Williams, C.C. and Bezeredi, S. 2018a. Explaining and tackling under-declared employment in FYR Macedonia: the employers perspective. The South East European Journal of Economics and Business 13(2): 19-31.

Williams, C.C., and Bezeredi, S. 2018b. Explaining and tackling the informal economy: a dual informal labour market approach. Employee Relations 40(5): 889-902.

Williams, C.C., and Efendic, A. forthcoming. Evaluating the relationship between migration and participation in undeclared work: lessons from Bosnia and Herzegovina. Economic Alternatives

Williams, C.C., and Franic, F. 2016. Beyond a deterrence approach towards the undeclared economy: some lessons from Bulgaria. Journal of Balkan and Near Eastern Studies 18(1): 90-106.

Williams, C.C., and Horodnic, I.A. 2016. Evaluating the policy approaches for tackling undeclared work in the European Union. Environment and Planning C: Politics and Space 35(5): 916-936.

Williams, C.C., and Horodnic, I.A. 2017a. Evaluating the relationship between social exclusion and participation in the informal sector in the European Union. International Manpower Journal 38(3): 489-503.

Williams, C.C., and Horodnic, I.A. 2017b. Evaluating the illegal employer practice of under-reporting employees' salaries. British Journal of Industrial Relations 55(1): 83-111.

Williams, C.C. and Horodnic, I. 2017c. Under-declaring work/ falsely declaring work: under-declared employment in the European Union. Brussels; European Commission.

Williams, C.C., and Horodnic, I.A. 2019a. Dependent selfemployment: theory, practice and policy. Cheltenham: Edward Elgar.

Williams, C.C., and Horodnic, I.A. 2019b. Evaluating working conditions in the informal economy: evidence from the 2015 European Working Conditions Survey. International Sociology 34(3): 281-306.

Williams, C.C., and Kayaoglu, A. 2017. Evaluating the prevalence of employees without written terms of employment in the European Union. Employee Relations 39(4): 487-502.

Williams, C.C., and Lapeyre, F. 2017. Dependent SelfEmployment: trends, challenges and policy responses in the EU. Geneva: Employment Working Paper 228, International Labour Organisation.

Williams, C.C., and Lapeyre, F. 2020. Dependent self-employment and newer forms of informal employment: trends, challenges and policy Responses in the EU. In Transition to Formality and Structural Transformation: Challenges and Policy options, edited by I. Islam and F. Lapeyre, 256311. Geneva: International Labour Organisation.

Williams, C.C., and Schneider, F. 2016. Measuring the Global Shadow Economy: the prevalence of informal work and labour. Cheltenham: Edward Elgar. 
Williams, C.C., and Windebank, J. 1998. Informal Employment in the Advanced Economies: implications for work and welfare. London: Routledge.

Williams, C.C., and Windebank, J. 2001. Reconceptualising paid informal exchange: some lessons from English cities. Environment and Planning A 33(1): 121-140.

Williams, C.C., Bejakovic, P., Mikulic, D., Franic, J., Kedir, A. and Horodnic, I.A. 2017a. An evaluation of the scale of undeclared work in the European Union and its structural determinants: estimates using the Labour Input Method. Brussels: European Commission.

Williams, C.C., Martinez-Perez, A., and Kedir, A.M. 2017b. Informal entrepreneurship in developing economies: the impacts of starting-up unregistered on firm performance. Entrepreneurship Theory and Practice 41(5): 773-799.
Williams, C.C., Horodnic, I., and Windebank, J. 2017c. Evaluating the internal dualism of the informal sector: evidence from the European Union. Journal of Economic Studies 44(4): 605-616.

World Bank 2019. Global economic prospects: darkening skies. Washington DC: World Bank.

World Bank. 2020. Air transport, passengers carried. https:// data.worldbank.org/indicator/is.air.psgr 